\title{
ÇEViRi
}

\section{Yazılı Anayasalar ve İdari Devlet: İdare Hukukunun Anayasal Karakteri Üzerine}

\author{
Tom GINSBURG \\ Çev: Nuray SÜMER ${ }^{*}$ \\ Gökhan SÜMER **
}

İdare Hukuku kamu hukukuyla eş anlamlı, ancak anayasa hukukunun gölgesinde, çok çalışkan, silik bir kuzeni gibi kamu hukukundan daha az önemli görülen bir alandır. Genel olarak, anayasa hukukunun devlet ve toplumun büyük meselelerini çözdügüne, idare hukukunun ise en iyi ihtimalle yalnızca idari devlete (administrative state) ilişkin temel ilkeleri açıklığa kavuşturduğuna inanılmaktadır. Hukuk öğrencileri, çoğu hukuk fakültesinde ders programında üç veya dört saat olarak öngörülen anayasa derslerine yoğun bir katılım gösterirken, aynı öğrenciler idare hukuku dersine adeta yapılması gereken bir angaryaymış hissiyle kaydolmaktadır.

Hiç kuşku yok ki, bu iki alan birbiriyle derinlemesine ilişkilidir ve devlet ve vatandaş arasındaki ilişkiyi yönetmek gibi - demokratik ülkelerde daha çok ikinciye önem verilerek - üstün bir amacı paylaşmaktadır. Buna karşılık, bu alanlar farklı hukuk kaynaklarından beslenmekte ve farklı yaklaşımlar göstermektedir. Bazı ülkelerde anayasa hukuku ve idare hukuku meseleleri tamamıyla farklı mahkemeler eliyle görülmektedir. Anayasa hukuku, hakimlerin düzenli olarak diğer ülke kararlarına atıflarıyla birlikte gittikçe daha çok karşılaştırmalı bir hal alırken, idare hukuku ulus devlet sınırlarına tıkanıp kalmış durumdadır.

Bu yazıda üç argüman ileri sürülecektir. Öncelikle, idare ve anayasa hukuku arasındaki kavramsal ayrımın oldukça geçişgen olduğu ve birçok özelliğinin yanı sıra, idare hukukunun anayasalardan daha anayasal olduğunun düşünülebileceği tartışılacaktır. İkinci olarak, yazılı anayasaların idari devleti daha az sınırladıkları gösterilecektir. Yazılı anayasaların rolü, daha ziyade bürokrasinin

\footnotetext{
* Araştırma Görevlisi, Erzincan Üniversitesi Hukuk Fakültesi İdare Hukuku Anabilim Dalı, nuraysumer@std.sehir.edu. tr, (ORCID ID: 0000-0001-7404-7811).

** Essex Üniversitesi Doktora Öğrencisi, gsumer@essex.ac.uk, (ORCID ID: 0000-0002-7158-8142).

*** $\mathrm{Bu}$ çalışma, Tom Ginsburg tarafından yazılan "Written Constitutions and the Administrative State on the Constitutional Character of Administrative law" makalenin çevirisidir ("Comparative Administrative Law", Ed. Susan Rose-Ackerman, Henry R. Luce ve Peter L. Lindseth, Research Handbook of Comparative Law Series, 2010, s.117-127). Çeviri için izin veren Sayın Prof. Dr. Tom Ginsburg’e ve çeviri konusunda yardımlarını esirgemeyen Glasgow Üniversitesi Öğretim Üyesi Sayın Prof.Dr. Esin Örücü’ye sonsuz teşekkürlerimizi sunuyoruz. ( Ç.n.)
} 
büyük ölçüde sessiz kaldığı idari devletin ve hesap verilebilirliğin daha kapsamlı gövdesini tesis etmektir. $\mathrm{Bu}$ durum, idare hukukuna esasında anayasalarda şekillendiği düşünülen önemli bir rol vermekte ve oldukça esnek ve dayanıklı olarak nitelendirilen görece bağımsız bir alan bırakmaktadır. Üçüncü olarak, bu çalışma, yapılan karşılaştırmanın yazılı anayasaların sınırlarını gün yüzüne çıkartmaya ve ulus devletlerin yazılı olmayan anayasalarının bir öğesi olan karşılaştırmalı idare hukukuna daha fazla dikkat çekmeye çalışarak sonlanacaktır.

\section{I.IDARE HUKUKUNUN ANAYASAL KARAKTERI ÜZERINE}

Geleneksel anlayış anayasa ve idare hukukunun, temel hakların korunması, bütçenin denetimi ve idarenin sınırlandırılması gibi benzer gayelere hizmet ettikleri şeklindedir. $\mathrm{Bu}$ görüşteki temel ayrım, bu alanların kamu hukuku hiyerarşisinde işgal ettikleri yerlere ilişkindir: anayasa hukuku devletin en üst normlarını düzenlemekte iken, idare hukuku normlar hiyerarşisinde önem itibariyle daha alt seviyede yer alan ikincil düzenlemeler yapabilmektedir.

Buna karşın, idare hukukunun birçok açıdan anayasa hukukundan daha 'anayasal' olarak anlaşılması gerektiğini düşünmekteyim. Anayasalara atfedilen büyük işlevleri düşünelim. ${ }^{1}$ Çoğu kimse anayasaların fonksiyonlarını esas olarak anayasalcilığın bizatihi kendisi veya idarenin sınırlandırılması olarak belirtmektedir. Anayasanın sınırlandırma işlevine ilişkin olarak idare hukukunun anayasa hukukuyla büyük oranda kesiştiği ve bu anlamda idare hukuku çok daha fazla günlük hayata temas ettiğinden daha geniş bir uygulama alanına sahip olduğu açıktır. Sıradan bir vatandaş, anayasada yer alan ceza yargılamasının güvenceleriyle yakından ilgilenen bir "şüpheli” olmadığı gibi, siyasi söylemlerinin sınırlandırılmasından kaygı duymakta olan bir "muhalif" de değildir. Sıradan vatandaş daha ziyade sürücü belgesi, ticari işletme ruhsatı, sosyal güvenlik ödemeleri ve vergiler gibi pek çok önemsiz işler için devletle yüz yüze gelmektedir. İște anayasalcılığın gerçeklerle yüzleştiği yer tam da burasıdır: nadiren farkedilen ve fakat çok sayıda vatandaşı etkilemesi olası olan idarenin keyfiliğinin sınırlandırıldığı ve öngörülebilirliğin gerçekleştiği yerdir. Bundan dolayıdır ki, idare hukukunun anayasalcı bir eğilim içinde olduğu ve tartışmaya açık bir biçimde daha çok insan açısından anayasa hukukunun büyük meselelerinden daha önemli olduğu açıktır.

Buna karşın anayasaların tek işlevinin anayasalcılık olduğunu söylemek güçtür. Gerçekten de, olgusal olarak sınırlı bir idare anlayışının benimsenmediği birçok ülkede de anayasalar mevcuttur. Ancak bu 'kağıt parçası' anayasalar dahi hiçbirşey başaramıyor değillerdir. ${ }^{2}$ Diktatörlüklerde dahi, anayasalar kurumlara faaliyet alanlarıla ilgili olarak yol haritası çizerler. Otokratik ve oligarşik sistemler, kamu düzenine ilişkin yapısal beklentilerde eşgüdümü sağlamaya ihtiyaç duyarlar ve anayasalar bu gibi beklentilerin karşılanmasında önemli rol oynayabilmektedir. Bazı durumlarda,

Breslin 2009.

2 Brown 2008. 
anayasal normlar elitler arasındaki çatışmanın çözümünde faydalı bir yapı öngörmektedir. ${ }^{3}$ Anayasaların bu işlevi sınırlı değildir, ancak idareyi yetkilendiren ve faaliyetlerini yerine getirmek üzere idari teşkilatı kuran bir tanımdan ibarettir. İdari teşkilatın kurulması işlevinin idare hukukundaki karşıllğ̆ını ise kanunlar gerçekleştirmektedir. Yasamanın devrine ilişkin olanlar hariç, bütün bu idare hukukuna ilişkin anayasal düzenlemeler uyuşmazlıklara neredeyse hiç konu olmazlar. ${ }^{4}$

Anayasaya atfedilen özelliklerden bir diğeri ise sembolik veya ifade ediciliktir. Anayasalar bazı ülkelerde kolektif bilinci yansıtır ve bazen de kendisi bölgesel ve etnik ayrımcilıkların üstesinden gelecek kolektif bir bilinç dahi yaratabilir. Örneğin, 1996 tarihli Kuzey Afrika Anayasası katılımın ve uzlaşmanın sembolü haline gelmiş, iktidardan gelen itirazlara ve büyük toplumsal kargaşalara rağmen popüleritesini sürdürmüştür. Etkili bir şekilde uygulanması yıllar almış olsa da, 1917 tarihli Meksika Anayasası’nın sembolik değeri de oldukça yüksektir. Anayasaların bu sembolik veya ifade edicilik özelliği, anayasa yapımının özelliğine dikkat çekmektedir. İşte bu, bizi biraraya/ toplum haline getirir (We the People that come together) ve böylelikle anayasa diğer devletlerden farklı ve yerel olan ulusu inşa eder.

Dolayısıyla anayasalar idareyi sınırlandırır, idari teşkilatı kurar ve devletler için önemli sembolik işlev görür. Bu işlevleri gerçekleştiren anayasaların yöntemleri de benzerdir. Anayasalar, yerel özellikleri yansıtarak partikülarist bir biçimde olağan siyaseti kolaylaştırarak, biçimlendirerek ve değiştirilemez temel kurallar manzumesini sağlayarak, değiştirilmez bir biçimde varlıklarını sürdürürler.

İdare hukuku, bütün bu işlevlerin tamamını olmasa da, birkaçını yerine getirebilmekte ve bunu daha az asli bir biçimde yapmaktadır. İdare hukukunda çok az çalışma, devlet-toplum ilişsisi söyleminin sembolik boyutlarını ele almaktadır. Örneğin kamu tüzel kişilerinin düzenlediği yönetmelikler hiçbir zaman değiş̧tirilemez değildir ve idari usul ve karar alma süreçlerine ilişkin öngörülen asıl araçlar tipik olarak kanun hükmünde, ancak koşullar değiştiğinde de ilke olarak tadil edilebilmektedir.

İlk iddiam, idare hukukunun yerelliği çoğu kez daha iyi aksettirdiği ve birçok devletin süreklililiğini idare hukukunun sağladığıdır. Anayasalar sadece sembolik düzeyde ve idare hukununun başaramadığı farklı fonksiyon icra ederler: sadece anayasaların insanları biraraya getiren veya ulusu inşa eden ortak anlayış etrafında yazıldığı söylenmektedir. Halbuki bu sembolizm, anayasaların kritik özellikleri olan dayanıklılığın ve yerelliğin yanlış anlaşılmasına dayanmaktadır ve bu anlayış aldatıcıdır. Anayasaların önemli bir sembol oluşu, esasında insanların anayasaların yapmadıkları şeyleri yaptıklarına inanmasından kaynaklanır. Halbuki idare hukuku rejimleri, buna karşın daha yerel ve daha süreklidir ve bu sebeple idarenin etkili düzenleyici işlemlerini anlamaya çalışmak daha fazla dikkate değerdir.

3 Borris 2002.

4 İdare hukukuna ilişkin anayasal düzenlemelere yönelik daha geniş bilgi için bknz. Ahdieh (yayına hazır) (Ç.n: makalede atıf bu şekildedir.) 


\section{A. YERELLIK: ANAYASALAR, IDARE HUKUKU REJIMLERINDEN DAHA FAZLA BENZERLIK GÖSTERIRLER}

Anayasa yapımı denilince aklımıza, devleti yetkilendirmek üzere biraraya gelen vatandaşların oluşturduğu ayrıcalıklı bir grup sahnesi gelir. Bu sosyal sözleşme sahnesi, geçici ve coğrafi olarak sınırlıdır. We the people, yerel değerlerimizin karakteristik yansıması olan anayasayı üretir. Ancak bu düş, birkaç noktada artık doğru değildir. Öncelikle, uluslararası aktörler de anayasa yapım sürecinde giderek artan bir şekilde pay sahibi olmakta ve tasarı oluşturma sürecinde esaslı bir konum işgal etmektedir. ${ }^{5}$ İkinci ve bununla ilişkili olarak, anayasalar zaman geçtikçe özünde birbirlerine yaklaşmaktadır. Araştırmanın ciddi bir kısmı göstermektedir ki, ulusal anayasa hükümleri, yerelin evrensel normlar karşısında ikinci plana düştüğü bir çeşit ulus modernizminin yazılı halini yansıtır hale gelmiştir. ${ }^{6}$ İdari teşkilatın temel şekillerinin de oldukça tahmin edilebilir değişiklikler gösterdiği görülmektedir.

Bunun sebebi ne olabilir? Anayasalar en üst hukuk normu olduğundan yansıtıcı unsurlara sahiptir ve bu unsurlar uluslararası toplumda sıklıkla ulus devleti temsil etmektedir. Anayasalar, egemenliğin ve modernleşmenin göstergeleridir: yalnızca idareyi yetkilendirmemekte, uluslararası düzlemde bu durumun tanınırlığını güvence altına almaktadır. Bunun sonucu olarak da, ciddi anlamda anayasalar arası benzerlikler söz konusudur.

Örneğin, insan hakları belgelerini düşünelim. Anayasal haklar manzumesi zamanla, bilhassa uluslararası insan hakları belgelerinin takip edilmesiyle birlikte birbirlerine benzeme eğilimi göstermiştir. ${ }^{7}$ Uluslararası antlaşmalar ve bölgesel insan hakları belgeleri, anayasa yapıcılar için adeta bir menüdür ve bundan dolayıdır ki zamanla anayasaların birbirlerine daha fazla benzedikleri hususu şaşırtıcı değildir. Bu olgusal gerçeklik için birçok olası açıklama getirilebilir. Bu benzerlik, bazı ülkelerin modernleşme ve modernleşmeyi yansıtan kurumları benimsemesi dolayısıyla bir dereceye kadar taklitinden de ileri gelebilir. İkinci bir şık olarak bu benzerlik, ülkelerin farklı kurumsal yapıların (configurations) niteliklerine ilişkin olarak birbirlerinden ve uluslarası kurumlardan edindikleri müşterek bilgilerden de kaynaklanabilir. Açıklama ne olursa olsun, sonuç şu ki anayasalar daha önce böyle nitelendirilmiş olsalar dahi, artık münhasıran yerel ürünler olarak değerlendirilemezler.

İdare hukukunda ise bunun aksi söz konusudur. Küresel gelişmeleri incelediğimizde, genel izlenim idare hukukunun ulusal kurumsal yapılara süregelen bağlılığıdır. Dört büyük hukuk sistemi olan Fransa, Almanya, Amerika ve İngiltere’yi ele aldığımızda, benzerlikler çıkartıldığında büyük kurumsal ve ideolojik ayrılıkların artakaldığı açıktır. Örneğin, Fransa’da idare hukuku geleneği ayrı ve otonom bir hukuk dalı olan droit administratifle birlikte Conseil d'Etat'daki uzman idarecilerin nezaretinde varlığını sürdürmektedir. ${ }^{8}$ Almanya'da idari yargı merciileri vardır ancak Fransız geleneğinden farklı olarak, yargıçlar tarafından denetlenen ilkelerin yer aldığı idari usul

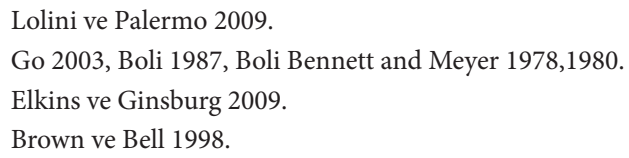


yasası etrafında uygulamasını şekillendirmektedir. Sorumluluk ve idari sözleşmeler rejimi Alman İdare Hukuku’nun alanı dışında bırakıldığından, kapsam olarak da gelenekler farklılaşmaktadır. ${ }^{9}$ Diğer taraftan, genel düzenleyici işlemler de idare hukuku sahasına dahil olabiliyorken; Alman İdare Hukuku, - Amerikan İdare Hukuku’nda daha fazla uygulaması olan - idari işlemlerin yapım sürecine halkın katılımından ziyade, temel haklara ilişkin meselelere daha fazla odaklanmaktadır.

İngiltere'de idare hukuku Dicey'in şüpheci fikirlerinin etkisi altında uzun süre güçlükle ilerleyebilmişti. ${ }^{10}$ Dicey, ayrı bir takım kurumların varlığındansa, common law mahkemelerinin denetiminini faydalı görmekteydi. Ancak modern devletin genişlemesiyle birlikte ortaya çıktı ki, itiraz başvurularındaki yoğun artış geleneksel küçük İngiliz yargısını istila etmiştir. Bunun sonucu olarak idari kararlara karşı itirazları incelemek üzere common law mahkemelerinden ayrı, bağımsız özel mahkemeler (tribunals) kurulmuştur. 2007 tarihli Özel Mahkemeler, Mahkemeler ve Mahkemelerin Yürürlüğ̈̈ Hakkında Kanun (Tribunals, Courts and Enforcement Act 2007) ile son yıllardaki reformlar bu kurumları güçlendirmeyi taahhüt etse de, bunlar Sağlık Hizmetleri, Göçmenlik ve Sosyal Yardım Kuruluşları gibi münferit bürokrasilere bağlı, özel ve ihtisaslaşmış yapılar olarak kalmışıır. ${ }^{11}$ Mahkemelerin, bağımsız bir yargı düzeninin sağlanması hususunda kanuni yükümlülükleri söz konusudur ve bunlar idarenin takdir yetkisinin sınırlarını ve idari usulü geliştirirken 'doğal hukuk' nosyonuna bağlı kalırlar. Buna karşın Amerika'da İdari Usul Kanunu, enerjisinin ciddi bir kısmını idari işlemin yapılış usulüne harcamakta ve işte tam da bu noktada idari devlette işlem yapım sürecindeki en büyük çarpışmaları sevk ve idare etmektedir.

Şüphesizki, farklı hukuksistemlerindeidare hukuku normlarında bazı benzerlikler bulunmaktadır. Çoğu sistem, eşitlik, orantıllık ve şeffaflık sorularıyla ilgilenmektedir. Herhangi bir kimse, dört büyük hukuk sisteminde idare hukukunu, pek çok sayıdaki olgusal durum karşısında sınırsız sayıda standardın uygulanabildiği mahkemelerde ortaya çıan - Conseil d'Etat'nın bir yargı organı olduğunu dikkate alarak - geniş anlamda içtihat hukuku olarak genelleyebilir. Yine de, her hukuk sistemi kendine has özelliklerini korumaktadır. Üstelik karşılaştırmalı anayasal yorumlarda dikkat çeken uluslararası mahkeme kararlarına atıflara idare hukukunda çok az rastlanmaktadır. ${ }^{12}$

İdare hukukunun anayasa hukukundan daha az benzerlik göstermesinin nedenlerinden biri, bu alanın kapsamı üzerinde bir uzlaşmanın olmayışıdır. Anayasalar, neredeyse bugün bütün modern devletler için saygı duyulan bir metin olarak (bununla sınırlı olmamakla birlikte) tarif edilmektedir. Oysa idare hukukunun sinırları konusunda daha az uzlaşı söz konusudur: her idare hukuku yapıları ağırlıklı olarak kendi sistemlerinin iç ve dış sınırlamalarına dayanmakta iken, sorumluluk rejimi, yargısal başvuru yolları veya diğer denetim mekanizmalarının kusursuz bir

9 Fransa’da idarenin sorumluluk esası Almanyảda olduğundan daha geniştir. Fransa’da idarenin kusursuz sorumluluğuna ilişkin düzenlemeler önemli bir yer kaplarken, Almanyảda idarenin ihmalinden kaynaklanan sorumluluğa ilişkin ilkeler ağırlık taşır (Singh 2001:257).

10 Lindseth 2005, Williams 1994.

11 Carnworth 2009.

12 Türkiyede ise tam tersine ulusal-üstü yargı mercilerine yapılan atıflar, Danıştay dergilerinde müstakil bir bölüm olarak yer almakta ve Avrupa'ya kıyasla daha fazla atıfta bulunulmaktadır. (Ç.n.) 
karışımında olduğu gibi kesin çizgiler - örneğin hukuk sistemlerine göre idari sözleşmelerin sözleşme hukuku içindeki yeri - farklılaşmaktadır. Bu noktada idari usul, söz konusu sınırların katılığını gidermekte ve kamu ve özel hukukun farklı anlayışlarını göstermektedir. Örneğin, Kıta Avrupası ve Japon hukuk sistemi, kamu ve özel hukuk arasında güçlü bir anlayış ve yaklaşım farkı çizmektedir. Amerikada ise, idari faaliyetleri gerçekleştirmek üzere özel hukuka sistematik bir şekilde başvurulması sonucunda ve dolayısıyla bir dal olarak idare hukukunun gerçek sinırları bir dereceye kadar daha geniş olduğundan, kamu-özel ayrımı daha az keskindir. Diğer taraftan özel hukuka başvurulmasında doğal hukuk ilkeleri ve pozitif düzenlemelerin göreceli birlikteliği de hukuk sistemlerinde çeşitlilik göstermektedir.

Kurumsal yapılar da değişiklik göstermektedir: Anglo-Amerikan sisteminde devletin eşitler arasında eşitlerin yargılandığı adli yargıda davaların tarafı olması hukuk devleti gereklerine dayanmakta iken, Fransa'da ve Almanyảda ayrı idare mahkemeleri söz konusudur. Ayrıca, idare hukuku sistemlerinde yargisal gelişmeler neredeyse her yerde belirgin bir rol oynasa da, hukuk sistemleri idare hukukunun öncelikli olarak yargı kararlarıyla mı yoksa yasama tasarruflarıly mı geliştiği ve ne ölçüde farklılaştığını da ortaya koymaktadır.

Kısacası, anayasa hukukunda hakimlerin diğer mahkeme kararlarını düzenli olarak atıfta bulunduğu ve anayasa yapıcıların yabancı ülke modellerini baz alması dolayısıyla benzerlik fazla iken, idare hukukunda durum böyle değildir. Belirli devletlerde çözüm unsurlarının cazibesini kaybetmesine neden olan kurumsal atalet, yerleşik siyasal çıarlar, teamüller ve kültürel tercihler idare hukukunda yeknesaklığın sağlamasına engel olmaktadır. Doktrin, kamu hukukunun şirketler veya özel hukuktan daha az benzerliğe sahip olması gerektiğini, çünkü bu alanın çıkarlardan ziyade değerleri yansıttığını ve dolayısıyla kısa dönemli ekonomik unsurlar tarafından şekillenmesinin daha az olası olduğunu ifade etmektedir. Profesör Schwarze ${ }^{13}$, idare hukukunu 'milli karakter' olarak ifade etmekte ve dolayısıyla göreceli olarak değişikliğe açık olmadığı şeklinde geleneksel argümanlarını listelemektedir.

İdare hukuku, idari kurumların işleyişiyle ilgilenmektedir ve bu kurumlar oluşturulması zor kurumlardır. Bir kere kurulduktan sonra, ortadan kaldırılması ise daha zordur. İdari kurumlardaki uygulama aksaklıklarını gidermek için tek yol, onlar üzerinde daha büyük kontrolü sağlayacak yolları araştırmaktır ve idare hukuku da ancak bu şekilde hedeflenen sorunların çözümünü teşkil eder. Bütün sanayileşmiş ülkelerin, geçen yüzyılda yaygın olarak idare hukuku müesseseleri geliştirmeleri bu sebeple şaşırtıcı değildir. Ancak ikincil düzenleyici işlemler gibi idari usuller de, söz konusu kurumlar etrafında şekillenmektedir. Oldukça fazla eleştirilen Amerikan İdari Usul Kanunu (APA), buna ilişkin getirilen pek çok öneriye karşın hiçbir değişikliğe uğramamıştır. Aynı şekilde, idare mahkemelerinin büyük bir anayasal devrim gerçekleşmedikçe de lağvedilmesi mümkün gözükmemektedir. Bugün bir yandan yeni idare mahkemeleri ve ihtisas kurullarının (benches) kurulmasına şahitlik ediyorken (örneğin son zamanlarda Japonyadakine benzer önerilerle Kore’de olduğu gibi), diğer yandan idare mahkemesinin adli yargıyla birleştirildiğini görmek neredeyse imkansızdır. Gerçekten de Fransa örneğinde, Anayasa Mahkemesi bireyin 
idari hakime başvurmasının anayasal bir hak olduğuna hükmetmiştir. Kısaca özetlemek gerekirse, bu atalet söz konusu değişikliği yasaklamakta ve kurumların lağvedilmesini zorlaştırmaktadır. Bundan dolayı da idare hukuku sistemlerinde esaslı farklılıklar görmekteyiz. Bu devam eden farklılaşmanın neticesinde ise şuanda belli konularda açık ve belirsiz uluslararası diyaloglara gömülmüş anayasa hukukundan farklı olarak, idare hukuku sistemleri yerelliği yansıtmaktadır. ${ }^{14}$

\section{B. DAYANIKLILIK: IDARE HUKUKU MÜESSESELERI DAIMI IKEN, ANAYASALAR DEĞILDiR}

Anayasa hükümlerinin değiştirilmesi zordur. Doktrin ve ilgililer anayasaların görece dayanıklı kurallardan müteşekkil olduğunu varsayarlar. Şüphesiz ki, anayasalar da değişikliğe konu olmaktadır ancak bu göreceli olarak daha az sıklıkla ve yeterince önemli görülen konularda söz konusu olmaktadır. Anayasalar, üst norm olduğundan sık değişikliklere karşı korunmaktadır. Gerçekten de anayasalcılık özünde belirli bir dayanıklılığı da gerektirmektedir.

Ancak yazılı anayasalar çoğu ülkede uzun süre varlığını, değişmeden sürdürememektedir. ${ }^{15}$ Sanayileşmiş demokratik ülkelerde dahi bu böyledir. Fransa (1791'den itibaren onbir Anayasa değişikliği geçirmiştir) 220 yıllık çok eski anayasası olan Amerikảan daha tipik bir örnektir. Anayasaların uzun süre değişmeden kalabildiği bölgelerden biri olan Batı Avrupa’da dahi ortalama bir anayasa yalnızca 30 yıllık bir geçmişe sahiptir ve dünyanın diğer bölgelerinde bu süre oldukça düşüktür. Anayasa değişiklikleri, bazen siyasal sistemlerin ve idarenin şeffalığını sağlamaya yönelik mekanizmaların tasarlandığı sert rejim değişiklikleriyle gündeme gelmektedir.

İdare hukuku müesseselerinde bunun tersi bir durum söz konusudur. Oldukça eski bir geçmişe sahip Conseil d'Etat, monarşi ve cumhuriyet, başkanlık ve parlamenter rejim, diktatörlük ve demokrasi arasında gitgellere rağmen hayatta kalmıştır. Bürokratik düzenin korunmasında ve idarenin kanuniliğinin sağlanmasında göreceli olarak özerk bir sistem kurmuştur. (Gerçekten de Fransız geleneğinde özerk konumunun sürekliliği dolayısıyla, anayasanın Conseil d'Etat'ya göre kesinlikle daha az tartışma konusu olduğu iddia edilebilir.) Fransa bu konuda yalnız değildir. İsviçre Ombudsman Kurumu 1809 'da kurulmuştur ve büyük siyasal yapı değişikliklerine rağmen ayakta kalabilmiştir ve Alman geleneğinde ayrı idare mahkemeleri sürekliliğini korumaktadır. ${ }^{16}$ Sovyet Procuracy'si, sayısız anayasa değişikliği geçirmiş ve gerçekten de Sovyet Rusya dönemi sonrası anayasalarda da mutlak rejim değişikliğine karşın kamu denetçiliği görevini sürdürmüştür. Doğu Avrupa örneğinde anayasalar kısa ömürlü olmasına karşın idare hukuku sistemleri görece daha dayanıklıdır. Tayland, 1932 yılından sonra onsekiz anayasa değişikliği geçiren en uç örnek olabilir, ancak Council of State etrafında örgütlenen bürokratik özerkliği, devam eden bir özelliği

14 Jakson 2009.

15 Elkins et al. 2009.

16 Japonya,1946 Anayasası ile idare hukuku sistemini değiştirmiştir. Müstakil idare mahkemelerinin bulunduğu Alman geleneğinden, yargı birliğinin benimsendiği Amerikan modeline geçmiştir. Bazıları, Japon hakimlerin isteksizliğini bu değişimle ilişkili olarak kurumsal kalıntıların idarenin faaliyetlerini sorgulamasına bağlamaktadır - adli yargı hakimlerinin idari ihtilafları değerlendirmekte özgüvenleri eksiktir. Haley 1991. 
olmuştur. ${ }^{17}$ Benzer şekilde Latin Amerika’da Amparo kurumu, anayasa değişikliklerine karşın yaygın bir şekilde kullanılmakta ve varlığını sürdürmektedir. ${ }^{18}$

Kurumsal yapılar yasal normlardan farklıdır. İdare hukuku normları teknolojideki gelişmelerle, şeffaf toplum oluşturma ve insan hakları konusundaki düşüncelerle birlikte değişmekte ve bütün bunlar anayasa metinlerinde yapilan değişiklikleri aksettirmektedir. Buna karşın, bu tartışma birçok örnekte idare hukuku yapılarının anayasal rejimlerde olduğundan görece daha fazla dayanıklı olduğunu göstermektedir. Gerçekten de idare hukukundaki dayanıklılık anayasal düzeydeki istikrarsızlı̆̆ın olumsuz etkilerini bertaraf etmektedir: siyasal kurumlar üzerinde çevrilen dolaplar her ne olursa olsun, vatandaş idareyle olan ilişkilerinde görece öngörülebilirliğe sahiptir.

\section{SEMBOLIZM: IDARE HUKUKU SISTEMLERININ IKINCILLIĞi}

Buraya kadarki tartışmayı özetlemek gerekirse, idare hukuku kurumları dayanıklıdır ve küreselleşme çağında dahi yerel özelliklerini koruyabilmektedir. Anayasa hukuku, buna karşıllık giderek uluslararasılaşmaktadır ve çoğu kez geçişgendir. Bu durumda, idare hukuku rejimlerinin anayasaların kendisinden daha iyi bir şekilde anayasal değerleri içselleştirdiği gözlemlenebilir.

Buna karşılık, ülke anayasalarının ayırtedici özelliği, sembolik ifadelerle ulusu biraraya getirmektir. Bütün anayasaların bu amacı etkili bir şekilde gerçekleştirdiği söyleyenemez ancak birçoğu için geçerlidir. Buna karşılık, idare hukuku anayasa hukukunun aksine sembolik nedenselliğe nadiren başvurmaktadır. Çevre kirliliğine yol açan maddelerin milyonda kaçının bir bacadan yayıldığına karar verilmesi öncesi düzenleyici kurulların kamuya açık bir duruşma gerçekleştirmesi hakkı veya bireyin sosyal güvenlik hakkının kaybına ilişkin mahrumiyet öncesi dinlenilme hakkına ilişkin ilkeler için insanların çok azı ölmeye isteklidir. Anayasa hukukunu tamamıyla farklı kılan şey işte burasıdır ve hangi anayasanın idare hukuku rejimlerinden daha fazla anayasal olabileceği de burada ortaya çıkmaktadır. Anayasalar idari devlete ilişkin ilkeleri açıklar ve bunu çoğunlukla uluslararası sahada yaparlar. We the People, bizim dünyadaki diğer insanlardan farklı olduğumuzu ve dolayısıyla anayasal kurumların milli bir karakteri olduğunu ifade etmek için kullanılmaktadır. Anayasal ifadeler bir dereceye kadar ülke sınırları dışına taştığından, anlaşılabilmesi için de müşterek bir dil kullanılmaktadır. Anayasal ifadelerdeki benzerlik, yazılı anayasaların farklı özelliklerinin aktarımını kısmen kolaylaştırmaktadır.

İdare hukuku sistemlerinin sembolik değerden yoksun olduğuna ilişkin çok şey söylenebilir. Bazı yazarlar, idarenin idari usul vasıtasıyla aktarıcı olduğundan bahsederler. Ancak idare hukuku sistemlerine atfedilen sembolik önemin derecesinin anayasa hukukundakine benzediğini iddia etmek zordur. Yazılı anayasalar büyük mücadelelere ve yüksek menfaatlere dayalı meseleleri düzenlediklerinden ülke tarihlerindeki büyük bağlantı noktalarına işaret etmektedir.

171997 Anayasası, Tayland idare hukuku için önemli sonuçları olan ilgili idari yargı düzenini kurarak, bu gelişmelere cevap vermiştir. Bu durum, söz konusu kuralın bir istisnasını teşkil etmektedir. Leyland 2008. 


\section{II.YAZILI ANAYASALAR VE IDARI DEVLET}

$\mathrm{Bu}$ kısımda, idare hukukunun anayasada ele alınış biçimi incelenecektir. Anayasaların temel fonksiyonlarından biri idarenin kuruluşunu düzenlemek iken, genel olarak yazılı anayasalar idari devlet konusunda görece çok az şey söylemeye meyillidir. Anayasada yasama ve yürütme erkinin faaliyet alanı ve oluşumuna ilişkin detaylı düzenlemeler yer alırken, alt siyasal kurumlar (subpolitical institutions) devamlı olarak veya bütün yönleriyle düzenlenmemektedir. Yazılı anayasalar idarenin düzenlenmesine ilişkin ayrıntılı kurallardan ziyade, idarecilerin işlemlerinin demokratik meşruiyetinin ve hesap verilebilirliğinin sağlanmasına yönelik ilkelere yoğunlaşma eğilimindedir. Bir diğer deyişle, anayasalar idarenin işlemleriyle değil, idarenin yapısıyla ilgilenmektedir.

Münferit yüzlerce çağdaş ve anayasal metinler araştırıldığında, bunlardan yalnızca bir avuç dolusu kadarı büroksiden bahsetmekte ve sıklıkla bürokrasiyi karakteristik bir tamlama (epithet) olarak kullanmaktadır. ${ }^{19}$ İdarenin kanuni sınırları bakımından ise, due processe ilişkin genel mülahazalar bilhassa regülasyon kurumlarına uygulanabilmektedir. ${ }^{20}$ Ancak hukuka uygun, makul ve usulen adil' hukuki muamele talep hakkı ve idarenin red işlemlerinin gerekçelerini talep hakkının anayasallaştığı Güney Afrika Anayasasının 33.maddesi gibi hükümler tamamıyla istisnadır. ${ }^{21}$ Daha geniş şekilde yer alan due processe ilişkin genel güvenceler (anayasaların yaklaşı \%10’unda yer almakta), çoğu kez cezai muhakeme usulü sınırlamalarıyla karşı karşıya kalmakta ve idarenin yargısal denetimini doğrudan kolaylaştıramayabilmektedir.

Yazılı anayasaların yönetim tekniğindeki (technology in governance) gelişmeleri takip etmekte olduğu açıktır. Bu sebeple, bağımsız idari otoritelerin ortaya çıkışı anayasal metinlere yansımıştır: 1789 Amerikan Anayasası tabii ki hiçbir bağımsız idari otoriteden bahsetmezken ('departmanlar'ı dahi çok az zikretmektedir), 1990larda yazılmış ortalama bir anayasa, bu kurumlardan en az üç tanesini içermektedir. Ombudsman, İnsan Hakları Kurumu gibi belli idari müesseseler ise daha da yaygınlaşmıştır: örneğin yürürlükte bulunan anayasaların yaklaşık yüzde yirmisinde Ombudsman Kurumu yer almaktadır. Yüzde ondan daha az anayasada ise, Yolsuzlukla Mücadele Komisyonuna yer verilmektedir. Tarihsel olarak, idari devletin denetlenmesine ilişkin en belirgin düzenleyici kurullar, Sayıştay (court of audit) veya bu işlerle ilgilenen kurullar olmuştur. Bu kurullar görece daha fazla görülmektedir: gerçekleştirdiğimiz projede (toplam yediyüz anayasa) bütün anayasal metinlerin yaklaşık yüzde yirmisi, bütçe hesaplarının denetimini gerçekleştirmek amacıyla kurulmuş bir kurum içermektedir. ${ }^{22}$

Anayasalarda idari devleti kurmanın diğer bir yolu ise, Kamu Hizmeti Komisyonu veya kariyer ve liyakat ilkelerine uygun istihdamın gerçekleşmesini temin edecek diğer kurumların

19 Örneğin, 1992 Vietnam Anayasası mad.112 (İdari devlette 'bürokrasiyle mücadele için’ yürütmenin yetkisi düzenlenmiştir). Bu örnek, Karşılaştırmalı Anayasalar Projesindendir, www.comparativeconstitutionsproject.org.

Örneğin, 1966 Dominik Cumhuriyeti Anayasası, Mad.8.2 (Suçta ve cezada kanunilik ilkesi); 1937 İrlanda Anayasası, Mad.38 (Hiç kimse, kanunun açıkça suç saymadığı bir fiilden dolayı cezalandırılamaz.)

21 Ayrica bknz. 1999 Kenya Taslak Anayasa metni, mad.70.

22 Detaylar için bknz. www.constitutionalmaking.org ve www.comparativeconstitutionsproject.org veya yazarla iletişime geçiniz. 
oluşturulmasıdır. Birçok toplumda devlet memurluğu oldukça fazla arzu edilen bir statü olmuştur ve bu statüyü iltimas için kullanılabilme ihtimali daha yüksektir. Liyakat esasına göre kamu görevlilerinin istihdamına yönelik getirilecek güvenceler anayasanın bir işlevidir. Örneğin, erken dönem 1824 yılı Brezilya Anayasası dahi, 'herkesin kamu hizmetine girme hakkına sahip olduğunu; görevin gerektirdiği niteliklerin aranılacağı”na ilişkin hükmü ihtiva etme gereği duymuştur. ${ }^{23}$ Çin Cumhuriyeti kamu sınavlarını gerçekleştirmek üzere Examination Yuan adlı bir erk kuracak kadar işi ileriye götürmüştür. Bu kurum bugün hala Tayvan’da da faaliyet göstermektedir ve hukuken yasama ve yürütme erkleriyle eşit bir statüdedir. Kurumun başkanı, başbakana denk bir statüdedir. Çin Cumhuriyeti, aynı zamanda yolsuzlukla mücadele ve bütçe denetimlerini gerçekleştirmek üzere bir Control Yuan kurmuştur. Bu yenilikler her ne kadar başka yerde uygulama alanı bulmasa da, bu kurumlara bugün oldukça gereksinim duyulmaktadır.

Son olarak, anayasalar idari yargıyı kurmak dolayısıyla da idare hukukuyla irtibat halindedir. $\mathrm{Bu}$ durum her zaman anayasalarda yer almasa da (bizim örneklemimizde yalnızca yaklaşık yüzde ikisinde mevcuttur), Meksika Anayasası'ndan Mongolya Anayasası̉na kadar çeşitli ülkelerde görülebilir. Fransız Anayasası dahi, esasen siyasal anayasanın bir ürünü olmayan Conseil d'Etat'dan yalnızca arızi olarak bahsetmektedir.

Ancak idari yargının anayasada düzenlenmesinin temelde çok önemli sonuçları bulunmaktadır. Şöyle ki bazı demokrasiye geçiş süreçlerinde gerçek anlamıyla hukuk devletini gerçekleştiren daha yüksek profilli anayasa mahkemeleri değil, idare mahkemeleridir. Hindistan ${ }^{24}$ ve Tayland ${ }^{25}$ bu duruma iki örnektir. Her iki durumda da, demokrasiye geçiş sürecinin bir parçası olarak oluşturulmuş bir anayasa mahkemesine, yeni veya son zamanlarda oluşturulan idare mahkemeleri eşlik etmiştir. Yine her iki durumda da, anayasa mahkemeleri yüksek profilli siyasi meselelerde hakemlik yapmak durumunda kalmış ve bu durumda kalan mahkemeye siyasi geri dönüşler menfi olmuştur. Buna karşın, idare hukuku sistemleri devletin daha alt seviyelerinde faaliyet göstermiş ve birçok yerde ilk defa, idarenin gerçek anlamda hukuka uygunluğunu sağlamaya hizmet etmişlerdir. $\mathrm{Bu}$ durum, daha düşük profilli idare mahkemelerinin, nasıl yüksek profilli anayasa mahkemelerine kıyasla anayasal değerlerin gelişmesine daha fazla fayda sağladığının bir göstergesidir.

Netice itibariyle yazılı anayasalar idarenin nasıl denetleneceğine ilişkin detaylar içermezler. İdari faaliyetler, idari sisteme yönelik yapısal hükümlerle ve sorumluluk mekanizması, ombudsman ve idare mahkemeleri gibi uzmanlaşmış denetim mekanizmaları ve liyakat esasına göre istihdam edilen kamu görevlileri aracılı̆̆ıla gerçekleştirilmektedir. İdare hukukunun işlev ve ilkelerinden birçoğunun anayasal karakterine karşın, birçok ülkede idare hukukunun işlevini anlayabilmek için yazılı anayasalar pek yardımcı olamamaktadır.

\footnotetext{
$23 \quad{ }^{11} 179 / 14 \mathrm{mad}$.

24 Bedner 2001.

25 Leyland 2008.
} 


\section{III.YAZILI OLMAYAN ANAYASALARIN BIR UNSURU OLARAK IDARE HUKUKU SISTEMLERI}

Son yıllarda, akademisyenlerin sözümona yazılı olmayan anayasalara ilgisi yeniden canlanmıştır. ${ }^{26}$ Kuşkusuz bütün anayasal sistemlerde, uzun süredir anayasal metinlerin dilinin siyasal aktörler ve yargı tarafından değiştirildiği ve yorumlandığı kabul edilmektedir. Amerika Birleşik Devletleri’nde, yüksek mahkeme yargıçları, anayasa yargılama usulünde açık bir düzenleme olmamasına rağmen, 18. yüzyıl müphem metninin detaylarını modern hayata uygun hale getirmek üzere yorumlamaktadır. Daha da kapsamlı bir biçimde, anayasal değişikliklerin anayasa-dışı çözüm yolları kısmen yazılı olmayan anayasal anlaşmaları gerektirmiş veya bunlara dayanmıştır. ${ }^{27}$

Anayasaların işlevleri, anayasanın kendisinden daha fazla yazılı metinler aracılığıyla hayata geçirilmektedir. Bazı kanunlar, resmi olmasa da uygulamada yerleşik hale gelmiş 'çerçevekanunlar' (super-statutes) olarak değerlendirilmiştir. ${ }^{28}$ Çerçeve-kanunlarla ilgili olarak doktrin, bilhassa düzenleme araçlarına dikkat çekmektedir, Sherman Antitrust Kanunu ve 1964 tarihli İnsan Haklar Kanunu gibi, usul kanunları da de facto değiştirilemeyen ve esasa ilişkin kapsamı dolayısıyla kriterleri karşılaması amacıyla bu sınıflandırmaya şüphesiz dahildir. İdari Usul Kanunları, önemli düzenlemeleri içeren ve bu düzenlemeleri uygulanır kılmak üzere oluşturulan meta-regulasyonlardır. Söz gelimi, Amerikan İdari Usul Yasasını (APA), anayasa statüsünde yer almayan ancak anayasal etkisi bulunan bir norm saymamak mümkün müdür? Bütün bunlar değerlendirildiğinde karşımıza çıkan sonuç belki de şudur: anayasalcılığa vücut veren yasal enstrumanlar araştırılırken bakış açımızı daha geniş tutmaya ihtiyaç vardır.

Yazılı olmayan anayasalara yöneltilen temel eleştirinin, dayanak sorunu olmasi saşırtıcı değildir. ${ }^{29}$ Bir hükmün anayasal olup olmadığını tespit ederken açık bir hüküm bulunmaması, yazılı olmayan anayasanın sınırlarını belirsiz hale getirir. Ancak bu bölümün başında yer alan tartışmanın anayasal sınırlara ilişkin kriterin artikülasyonuna yardımcı olması imkan dahilinde görülebilir. Anayasalar, gördüğümüz üzere devlet ve birey arasındaki ilişkiyi düzenlemeye odaklanmıştır ve görece dayanıklı oldukları farz edilir. Anayasa dışında yazılı olmayan anayasal hükümlerin neler olabileceği üzerine düşünüldüğünde, daha dayanıklı olan ve devlet ve toplum ilişkisini düzenleme iddiasında olan hükümlerin bu tanım içerisinde yer alması gerektiği açıktır.

O halde idare hukuku sistemlerini, temelinde anayasal karakter taşıormuş gibi ele almanın normatif sonuçları nelerdir? Birincisi, her zaman en önemli mesele olmasa bile böylesi bir anayasal gerçekçilik, anayasal değerlerle çokça karşı karşıya gelinen alanlara odaklanmamıza

Grey 1978, Ackerman 2007, Young 2008, Tribe 2008.

Ackerman 1993, Munro 1928, Tiedeman 1890

Eskridge ve Ferejohn 2005.

Yazar burada, modern pozitivist hukukçu olan Hart'ın 'the rule of recognition' tartışmasına atıf yapmaktadır. $\mathrm{Bu}$ tartışma, yasama tarafından usulüne uygun olarak çıkartılmış bir metne dayanmayan bir düzenlemenin, hukuk kuralı olarak nasıl kabul edilebileceğine yönelik eleştirileri/görüşleri içermektedir. Detaylı bilgi için bknz. H.L.A. Hart, Concept of Law, Clarendon Law Series 1961 (Ç.n.) 
yardımcı olur. Sürücü ehliyetleri veya yapı ruhsatiyesi gibi rutin meseleler, her zaman çok büyük sembolik ağırlığa sahip olmasalar bile, anayasa metnindeki yüce ilkelere kıyasen daha fazla insanın hayatında farklılık oluşturmaktadır. İkinci olarak, devlet ve vatandaşların mikro seviyedeki etkileşimlere odaklanması, şimdiye dek hukukun üstünlüğünün merkezi aktörler tarafından idame ettirildiği inancıyla anayasa mahkemelerinde toplanması istenen dikkati de dağıtmaktadır. Anayasa mahkemeleri, tabiatları gereği münhasır ve yüksek yargı yeri olmaları hasebiyle devleti sınırlandırma görevleri, sıkça yüksek profilli siyasete bulaştırılarak baltalanmaktadır. İdare mahkemeleri ise bu tür durumlarda birçok açıdan daha önemli hale gelmektedir. Netice itibariyle böylesi bir yaklaşım, karşılaştırmalı idare hukuku disiplininin öneminin altını çizmeye yardımcı olmaktadır. Her ne kadar bu alan yeni doğmuş olsa da söz konusu alanda yayınlanmış birçok makale bu disiplinin zengin imkanlarına dikkat çekmektedir.

\section{KAYNAKÇA}

ACKERMAN, Bruce. (1993), We The People, Cambridge, MA: Harvard University Press.

ACKERMAN, Bruce. (2007), 'The Living Constitution', Harvard Law Review, 120: 1737-812.

AHDIEH, Robert B. (Forthcoming.) 'The New Regulation: From Command to Coordination in the Modern Administrative State', manuscript.

BARROS, Robert. (2002), Constitutionalism and Dictatorship: Pinochet, the Junta, and the 1980 Constitution, New York: Cambridge University Press.

BEDNER, Adriaan. (2001), Administrative Courts in Indonesia: A Socio-legal Study, Boston: Kluwer Law International.

BOLI, John. (1987), 'Human Rights or State Expansion? Cross-national Definitions of Constitutional Rights, 1870-1970', in George Thomas et al., eds., Institutional Structure: Constituting State, Society, and the Individual, Beverley Hills, CA: Sage Publications.

BOLI-BENNETT, John and John W. Meyer. (1978). 'The Ideology of Childhood and the State', American Sociological Review, 43: 797-812.

BOLI-BENNETT, John and John W. Meyer. (1980). 'Constitutions as Ideology', American Sociological Review, 45: 525-27.

BRESLIN, Beau. (2009). From Words to Worlds: Exploring Constitutional Functionality, Baltimore, MD: Johns Hopkins University Press.

BREWER-CARİAS, Alain. (2008). The Constitutional Protection of Human Rights in Latin America: A Comparative Study of Amparo Proceedings, New York: Cambridge University Press.

BROWN, Nathan. (2008). 'Reason Interest Rationality and Passion in Constitution Drafting', Perspectives on Politics, 6: 675-89.

BROWN, Neville L. and John S. Bell. (1998). French Administrative Law, 5th edition, New York: Oxford University Press.

CARNWORTH, Robert. (2009). 'Tribunal Justice: A New Start', Public Law, 2009: 48-69, at http://www. chba.org.uk/library/seminar_notes/?a=75725.

ELKİNS, Zachary and Tom Ginsburg. (2009). 'Constitutional Convergence in Human Rights', manuscript. Elkins, Zachary, Tom Ginsburg and James Melton (2009). The Endurance of National Constitutions, New York: Cambridge University Press. 
ESKRİDGE, William and John Ferejohn. (2005). 'Super-statutes', Duke Law Journal, 50: 1215-75. GO, Julian. (2003). 'A Globalizing Constitutionalism? Views from the Postcolony, 1945-2000', International Sociology, 18: 71-95.

GREY, Thomas C. (1978), 'Origins of the Unwritten Constitution: Fundamental Law in American Revolutionary Thought', Stanford Law Review, 30: 843-93.

HALEY, John. (1991), Authority without Power: Law and the Japanese Paradox, New York: Oxford University Press. JACKSON, Vicki C. (2009), Constitutional Cosmology and Transnational Engagements, New York: Oxford University Press.

LEYLAND, Peter. (2008), 'The Emergence of Administrative Justice in Thailand under the 1997 Constitution, in Tom GINSBURG and Albert Y.C. Chen, eds., Judicialization and Governance in Asia, London: Routledge.

LINDSETH, Peter. (2005), “Always Embedded” Administration: The Historical Evolution of Administrative Justice as an Aspect of Modern Governance', in Christian Joerges, Bo Strath and Peter Wagner, eds., The Political Construction of Modern Capitalism, London: GlassHouse Press.

Lollini, Andrea and Francesco Palermo. (2009). 'Comparative Law and the "Proceduralization" of Constitution - building Processes', in Julia Raue and Patrick Sutter, eds., Facets and Practices of State-Building, Boston: Martinus Nijhoff, 301-26.

MUNRO, William Bennett. (1928). Makers of the Unwritten Constitution, New York: Macmillan. Schwarze, Jürgen. (2004), 'Enlargement, The European Constitution, and Administrative Law', International and Comparative Law Quarterly, 53: 969-84.

SINGH, Mahendra P. (2001), German Administrative Law in Common Law Perspective, 2nd edition, New York: Springer.

TIEDEMAN, Christopher. (1890), The Unwritten Constitution of the United States, New York: G.P. Putnam and Sons.

TRIBE, Laurence. (2008), The Invisible Constitution, New York: Oxford University Press.

WILLIAMS, David. (1994), 'Law and Administrative Discretion', Indiana Journal of Global Legal Studies, 2: 191-211.

YOUNG, Ernest A. (2008), 'The Constitution Outside the Constitution', Yale Law Journal, 117: 100. 